\section{Response to: 'Antinuclear antibody as entry criterion for classification of systemic lupus erythematosus: pitfalls and opportunities' by Bossuyt et al}

We very much appreciate the comments of Willems et $a l^{1}$ on our article on the variability of antinuclear antibody (ANA) testing for patients with established systemic lupus erythematosus (SLE). ${ }^{2}$ Others have provided their perspective on test variability. ${ }^{3-6}$ In their letter, Willems et al discuss the importance of antibody titre especially in the context of patient classification. In the new classification criteria under development, a positive ANA at a titre of 1:80 or higher is required. ${ }^{7}$ In view of our findings on assay variability, we have also commented on the use of serology as the initial element in classification. ${ }^{8}$ Without specification of the kit used and its performance characteristics, uncertainty about this key element of classification can occur.

The study presented by Willems et al provides valuable data on ANA detection by two assay formats-an immunofluorescence assay or IFA and a solid phase assay-for the broad range of patients with autoantibody-associated systemic rheumatic diseases (AASRD). Of note, among their patients with established SLE, 10\% showed negative results, consistent with our findings ${ }^{2}$; interestingly, six out of eight of the IFA-negative patients showed antibody positivity with the solid phase assay. Together, these studies highlight the complexity of serological testing and emphasise that, whatever the purpose of such determinations-disease classification or clinical trial eligibility-it is important to take into account the performance characteristics of any particular assay, including the titres obtained.

Serological testing is a key element in the diagnosis and management of patients with AASRD because of the utility of the ANA as a biomarker especially when coupled with assays for antibodies to specific antigens. Unfortunately, standardisation remains an issue and we look forward to further studies like those of Willems et al to alert the field to a problem that is often not adequately recognised especially if the IFA is called the 'gold standard'. Despite decades of investigation, the field is not yet at the point where any one kit or assay is uniformly successful and has achieved the 'gold standard' status. Pending more technological advances, the use of a combination of formats (ie, IFA and solid phase) may be the best solution to fulfil the need to classify patients and identify those who are eligible for new treatments.
David S Pisetsky, ${ }^{1}$ Diane M Spencer, ${ }^{1}$ Peter E Lipsky, ${ }^{2}$ Brad H Rovin ${ }^{3}$

${ }^{1}$ Department of Medicine and Immunology, Duke University Medical Center and Medical Research Service, VA Medical Center, Durham, North Carolina, USA

${ }^{2}$ RILITE Research Institute, Charlottesville, Virginia, USA

${ }^{3}$ Division of Nephrology, The Ohio State University, Columbus, Ohio, USA

Correspondence to Dr David S Pisetsky, Department of Medicine and Immunology, Duke University Medical Center, Durham, NC 27705, USA; david.pisetsky@duke.edu

Handling editor Josef S Smolen

Competing interests None declared.

Patient consent Not required.

Provenance and peer review Commissioned; internally peer reviewed.

(c) Author(s) (or their employer(s)) 2019. No commercial re-use. See rights and permissions. Published by BMJ.

\section{Check for updates}

To cite Pisetsky DS, Spencer DM, Lipsky PE, et al. Ann Rheum Dis 2019;78:e77.

Received 5 June 2018

Accepted 8 June 2018

Published Online First 23 June 2018

\section{SLinked}

http://dx.doi.org/10.1136/annrheumdis-2018-213821

Ann Rheum Dis 2019;78:e77. doi:10.1136/annrheumdis-2018-213841

\section{REFERENCES}

1 Willems P, De Langhe E, Westhovens R, et al. Antinuclear antibody as entry criteria for classification of systemic lupus erythematosus: pitfalls and opportunities. Ann Rheum Dis 2018;78:e76.

2 Pisetsky DS, Spencer DM, Lipsky PE, et al. Assay variation in the detection of antinuclear antibodies in the sera of patients with established SLE. Ann Rheum Dis 2018;77:911-3.

3 Mahler M. Lack of standardisation of ANA and implications for drug development and precision medicine. Ann Rheum Dis 2019;78:e33.

4 Meroni PL, Chan EK, Damoiseaux J, et al. members of the committees. Unending story of the indirect immunofluorescence assay on HEp-2 cells: old problems and new solutions? Ann Rheum Dis 2019;78:e46.

5 Pregnolato F, Borghi MO, Meroni PL. Forum Interdisciplinare per la Ricerca sulle Malattie Autoimmuni (FIRMA) Study Group. Pitfalls of antinuclear antibody detection in systemic lupus erythematosus: the positive experience of a national multicentre study. Ann Rheum Dis 2019;78:e50.

6 Van Hoovels L, Schouwers S, Van den Bremt S, et al. Variation in antinuclear antibody detection by automated indirect immunofluorescence analysis. Ann Rheum Dis 2019:78:e48.

7 Tedeschi SK, Johnson SR, Boumpas D, et al. Developing and refining new candidate criteria for systemic lupus erythematosus classification: an international collaboration. Arthritis Care Res 2018;70:571-81.

8 Pisetsky DS, Lipsky PE. The role of ANA determinations in classification criteria for SLE. Arthritis Care Res 2018. doi: 10.1002/acr.23559. [Epub ahead of print 26 Mar 2018]. 